Stawomir Zatwardnicki

Papieski Wydział Teologiczny we Wrocławiu

\title{
Przebóstwienie w perspektywie teologii i mistyki \\ Synteza dwóch mądrości \\ „bez zmieszania i bez rozdzielania”
}

\section{DIVINIZATION IN THE PERSPECTIVE OF THEOLOGY AND MYSTICISM. SYNTHESIS OF TWO WISDOMS "INCONFUSEDLY AND INDIVISIBLY"}

Benedict XVI showed the mistery of divinization in the Christological perspective. It takes place similarly to the way two natures are united in one Person of the Son of God (the Council of Chalcedon). The way two wills (human and divine) are united in one in Christ is a condition and model of communion of God's will and a man's one (the Third Council of Constantinople). The article deals with the coherence between dogmatic statements and saints as well as mistics' experience (John of the Cross, Faustyna Kowalska, Maksymilian Kolbe). Synthesis of dogmatics and mysticism allows to better understand what theosis is and how it takes place.

Key words: Benedict XVI, Christ, God, man, Mary, divinization, the Council of Chalcedon, the Third Council of Constantinople, union, mysticism, theology, Christology, anthropology, nature, will, John of the Cross, Faustyna Kowalska, Maksymilian Kolbe. 


\section{Wstęp. Człowiek jakby sobowtórem Boga (św. Tomasz)}

Już zostaliśmy nazwani przez Ojca i rzeczywiście jesteśmy dziećmi Bożymi, a choć jeszcze się nie ujawniło, czym będziemy (por. $1 \mathrm{~J} 3,1$ ), to przecież - powiada autor natchniony - „wiemy, że gdy się objawi, będziemy do Niego podobni, bo ujrzymy Go takim, jakim jest” (1 J 3, 2). Papież Leon Wielki wiązał chwalebną przyszłość z tajemnicą Wcielenia - w jednym ze swoich kazań głosił, że Chrystus „w ciele naszym przyszedł na świat, abyście zasłużyli sobie patrzeć weń kiedyś w niebie jako w Boga chwały"1. W jaki jednak sposób stworzenie może ujrzeć Stwórcę? Podpowiada św. Tomasz z Akwinu, że do widzenia istoty Boga potrzebuje człowiek odpowiedniego przystosowania, które podniesie naturę ludzką ku poziomowi ją przekraczającemu². Według Doktora Anielskiego światłość (jasność) Boża oświeci niebian w Niego wpatrzonych (por. Ap 21, 23), dzięki czemu będą podobni do Niego - doznawszy przebóstwienia „stają się jakby «sobowtórami» Boga (deiformes)"3. W objawionych słowach - „ujrzymy Go takim, jakim jest" - należy według Tomasza słyszeć zapewnienie o doskonałym ujawnieniu się istoty Boga, a nie miarę stopnia naszego widzenia, które nie jest tak doskonałe jak sposób bytowania Boga. Doktor Kościoła uważał, że nie wszyscy będą się cieszyć oglądaniem Boga w Jego istocie w stopniu równie doskonałym, bowiem ogląd ten zależeć będzie od siły i pojemności myśli oglądającego; im większe ktoś przyjmie światło chwały przebóstwiające myśl człowieka, tym doskonalej widzieć będzie Boga, z kolei większe światło chwały przypada temu, kto obfituje w większą (gorętszą) miłość Boga .

Ale czy w takim razie należałoby stawiać jakieś granice doskonałości oglądania Boga? Czy przebóstwiony człowiek staje się jedynie pomniejszonym „sobowtórem” Boga? Albo inaczej: na jaką „wysokość” podnosi człowieka Bóg, który w Chrystusie staje się człowiekiem na „niskości”? Czy Ten, który, mówiąc językiem proroka, schyliwszy się podniósł człowieka jak ojciec niemowlaka do swojego policzka - więcej: sam stał się takim niemowlakiem, do którego policzka człowiek się przytulił (Maryja!) - miałby pociągnąwszy człowieka ludzkimi więzami miłości (por. Oz 11, 4), nie dać mu wypływającego z doskonałej miłości Bożej

$1 \quad$ Św. Leon Wielki, Mowa 22, nr 6. Korzystam z wydania: Św. Leon Wielki, Mowy (Pisma Ojców Kościoła, 24), tłum. K. Tomczak, Poznań-Warszawa-Lublin 1958 [dalej cyt. LWM, numer mowy, numer punktu].

Por. Św. Tomasz z Akwinu, Suma Teologiczna I, q. 12, a. 5.

Tamże.

Por. Św. Tomasz z Akwinu, Suma Teologiczna I, q. 12, a. 6. 
całego dziedzictwa, a więc również - samego siebie? Według św. Maksyma Wyznawcy (ok. 580-662), greckiego Ojca Kościoła, przebóstwiony człowiek otrzymuje wszystko to, co posiada Bóg, poza tożsamością istoty ${ }^{5}$. Problemem pierwszych rodziców (oraz ich potomków, więc i autora, i Czytelników niniejszego artykułu) nie jest tęsknota za byciem , jak Bóg”, ale sposób realizacji tego pragnienia. Przeznaczony do przebóstwienia człowiek - twierdzą autorzy Katechizmu w odwołaniu do przed chwilą wspomnianego piewcy przebóstwienia oraz obrońcy ortodoksyjnej chrystologii - ,zwiedziony przez diabła, chciał «być jak Bóg», ale «bez Boga i ponad Bogiem, a nie według Boga»"6. Zbawiciel nasz, według słów Leona Wielkiego, „właśnie dlatego stał się synem człowieczym, abyśmy mogli zostać synami Bożymi”, i właśnie Wcielenie jest warunkiem naszego przebóstwienia, bowiem gdyby „On nie zstąpił do nas w tym uniżeniu, nikt nie zdołałby wznieść się do Niego przez jakąkolwiek swoją zasługę"7. Wydaje się, że w fakcie Wcielenia (uczłowieczenia) Boga można dopatrywać się pełnego „wbóstwienia” (przebóstwienia) człowieka, na zasadzie symetryczności sugerowanej przez formułę św. Atanazego: „Bóg stał się człowiekiem, by człowiek mógł stać się Bogiem”.

W odpowiedzi na powyższe pytania - niezbędnej, że właśnie Dobra Nowina o przebóstwieniu okazać się musi remedium na podejmowane wciąż na nowo próby samoubóstwienia człowieka, dziś wzmagające się chyba z niespotykaną wcześniej siłą - pomocne może okazać się spojrzenie na przebóstwienie z perspektywy zarówno teologii jak i mistyki. W nadziei, że wnioski obu typów mądrości mogą ustanowić dzięki wzajemnemu naświetlaniu się „,jaśniejszą jasność”, w której dane będzie zobaczyć więcej z istoty przebóstwienia, niż wtedy, gdy oba typy wiedzy widzi się jako „rozdzielone” (zamiast „rozróżnienia” ich bez zrywania jedności między nimi).

Dogmatyka podpowie nam, że na przebóstwienie należy oczywiście patrzeć z perspektywy Wcielenia, jak na zjednoczenie człowieka z Bogiem dokonujące się na wzór i na fundamencie zjednoczenia dwóch

5 Por. również: Ch. Schönborn, Przebóstwienie, życie i śmierć, tłum. W. Szymona, Poznań 2001, s. 43: „«Człowiek przebóstwiony przez łaskę otrzymuje dla siebie wszystko, co posiada Bóg - poza tożsamością istoty». Wszystko! - można by się dopatrywać tutaj retorycznej przesady. Jednak cała zachodnia i wschodnia Tradycja to właśnie ma na myśli, kiedy mówi o łasce przebóstwienia: kto zostanie zaszczycony łaską przebóstwiającą, ten otrzymuje nie «jakąś część» lub «coś» z Boga, ale otrzymuje Go rzeczywiście całego. Tak Ojcowie rozumieją uczestnictwo w życiu Bożym, jako celu naszego istnienia”. 
natur w jednej Osobie Syna Bożego, bez przekreślenia człowieczeństwa, ale też bez rozdzielania człowieka od Boga (chalcedońskie: „bez zmieszania i bez rozdzielania"8). Wszak w tym samym rozdziale Księgi Objawienia, do której odwoływał się św. Tomasz, jesteśmy nazwani Jego ludem, a On - „Bogiem z nami” (por. Ap 21, 3)! Nowe Przymierze, które stało się naszym udziałem dzięki temu, że Bóg przez swoje Wcielenie stał się „Bogiem z nami” (Mt 1, 23), nie jest - cytuję Katechizm Kościoła Prawostawnego -

tylko paktem między Bogiem a człowiekiem, zwykłą wymianą obietnic, zwykłym porozumieniem między dwiema stronami. Nowe Przymierze to coś więcej: to głęboka, jakby małżeńska, jedność między Bogiem i człowiekiem (...) Bóg, który stał się człowiekiem, daje Boga człowiekowi, który w Niego wierzy9.

Dzięki mistyce zajrzymy „za zasłonę” doktryny - praktyczne doświadczanie oblubieńczej miłości Bosko-ludzkiej pozwoli być może lepiej zrozumieć samą tajemnicę „stawania się Bogiem”, a na pewno ukaże głębię zjednoczenia Boga i człowieka. W niniejszym tekście sięgnę zarówno do słabo wykształconej mistyczki św. Faustyny, która całą swą mistyczną wiedzę czerpała z tego, co przeżyła, jak i do wykształconego Jana od Krzyża, mistyka łączącego doświadczenie z wiedzą teologiczno-filozoficzną, co jest tym bardziej wskazane, że nauki Doktora Nocy wykazują związki właśnie z Tomaszem z Akwinu ${ }^{10}$. Oczywiście niniejsze rozważania są nie tyle próbą dyskusji z Tomaszowym przekonaniem o różnych stopniach doskonałości przebóstwionych, ile mają raczej służyć poszukiwaniu odpowiedzi na pytanie o to, jak bardzo człowiek jako „sobowtór” Boga podobny stać się może Boskiemu oryginałowi ${ }^{11}$. Innymi słowy: jak „dalece” (głęboko, wysoko, szeroko)

8 Por.Breviarium fidei. Wybór doktrynalnych wypowiedzi Kościoła, opr. S. Głowa, I. Bieda, Poznań 1998, s. 226: „....jednego i tego samego Chrystusa Pana, Syna Jednorodzonego należy wyznawać w dwóch naturach, bez zmieszania, bez zmiany, bez rozdzielania i rozłączania".

Bóg żywy. Katechizm Kościoła Prawosławnego. Opracowany przez zespót wiernych prawostawnych, tłum. A. Kuryś i in., Kraków 2001, s. 174-175.

$\mathrm{Na}$ ten związek zwrócił uwagę Jacques Maritain, który uważał „św. Jana od Krzyża za wielkiego doktora najwyższej niekomunikatywnej wiedzy, podobnie jak św. Tomasza za wielkiego doktora wiedzy komunikatywnej" - por. O. Filek, Wprowadzenie, [w:] Św. Jan od Krzyża Doktor Kościoła, Dzieła, tłum. B. Smyrak, Kraków 1998 [dalej cyt. JKD], s. 57.

11 Święty Augustyn uważał na przykład, że przebóstwiony jest bogiem ,,jedynie do pewnego stopnia. Najwyższy pułap, jaki człowiek może osiągnąć, to równość i podobieństwo do aniołów w błogosławionym oglądaniu Boga..." (A. Eckmann, Przebóstwienie człowieka w pismach wczesnochrześcijańskich 
człowiek może zostać napełniony całą pełnią Bożą (por. Ef 3,18 ). W rozwiązaniu tej kwestii należy skierować się oczywiście ku „Matce przebóstwionych", która najdoskonalej odpowiedziała miłością na miłość Boga, a zatem jest najbliżej Niego. W odkrywaniu Maryjnego zjednoczenia z Bogiem warto sięgnąć do intuicji św. Maksymiliana Marii Kolbego, z kolei wielkość Maryi ukaże pośrednio „zdolność” natury ludzkiej do poddania się przebóstwieniu.

\section{Mistyka i teologia w perspektywie formuły Chalcedonu (Międzynarodowa Komisja Teologiczna)}

\section{O uwzględnienie doświadczenia mistycznego w interpretacji przebóstwienia}

Jeśli jest prawdą, że ,szczególny charakter godności ludzkiej polega na powołaniu człowieka do łączności z Bogiem” ${ }^{12}$, nie dziwi, iż „ojcu kłamstwa" zależy na zerwaniu tej łączności, z którą właśnie wielkość powołania człowieka nierozerwalnie jest związana. Diabeł w krzywym zwierciadle ukazał zarówno człowieka, jak i Boga; odwieczną i uzasadnioną tęsknotę ludzi do tego, by stać się Bogiem, skierował szatan na manowce - ukazując błędną drogę ku jego realizacji, co z kolei było możliwe tylko dlatego, że Adam i Ewa przyjęli wcześniej nieprawdziwe obrazy Boga i samych siebie zaprezentowane im przez przeciwnika Boga i człowieka. Ostatecznie przecież ani nie ma takiego Boga, jakim zamarzyło stać się pierwszym rodzicom - Bóg nie chowa się przed człowiekiem, owszem daje mu się cały - ani nie jest prawdą o człowieku, że może zanegować swoje człowieczeństwo. Ciekawe, że przebiegłość węża doprowadza człowieka do tak absurdalnej naiwności: przyjąwszy, że Bóg nie miłuje człowieka, chce się człowiek stać takim niemiłującym człowieka bogiem, co prowadzić musi albo do absurdu istnienia (człowiek i Bóg odrzucający człowieka w jednej osobie), albo wprost do śmierci człowieka (gdy ten staje się „Bogiem” przez ucieczkę od człowieczeństwa). A upadły anioł łgał: „Na pewno nie umrzecie!" (Rdz 3, 4).

(Źródła i monografie - Towarzystwo Naukowe Katolickiego Uniwersytetu Lubelskiego, 249), Lublin 2003, s. 110).

12 Sobór Watykański II, Konstytucja duszpasterska o Kościele w świecie wspótczesnym „Gaudium et spes”, nr 19. Korzystam z tłumaczenia konstytucji [w:] Sobór Watykański II, Konstytucje, dekrety, deklaracje. Tekst polski. Nowe ttumaczenie, Poznań 2002, s. 526-606. 
Opowiadanie o upadku w Raju zachowuje swoje znaczenie dla wszystkich potomków Adama i Ewy, dodatkowo jeszcze obciążonych skutkami grzechu prarodziców oraz swoimi. Może w takim razie lepiej zapomnieć o przebóstwieniu, skoro wiąże się z tym realne niebezpieczeństwo uległości pokusie samoubóstwienia? Czy jednak nie byłoby to zdradą człowieczeństwa i niewiernością Bogu, a także przekreśleniem Jego zbawczej misji? Trzeba szukać „wąskiej ścieżki”, by móc zaspokoić „po Bożemu” to ludzkie pragnienie, wszczepione przez samego Boga, bycia większym od siebie samego, a nie mniejszym od Boga. Jeśli „wąż tłumaczy, że wydany przez Boga zakaz jedzenia owoców z drzewa poznania wynikał z boskiej zazdrości"13, jak odparłszy tę pokusę oskarżenia Boga o zazdrość, samemu nie ulec zazdroszczeniu Bogu tego, czego zazdrościć człowiekowi - istocie stworzonej - nie wolno? Jak odrzucić pokusę nieufności względem Boga, a jednocześnie nie stracić ufności względem samego siebie? W którym „momencie” pytać może człowiek skażony grzechem, z trudem poznający siebie i Boga - rzeczywiste pragnienie bycia jak Bóg przeradza się w jego wynaturzenie, a człowiek zbacza z drogi do celu do Boga oraz do samego siebie?

Ojcowie Kościoła pod pojęciem zbawienia rozumieli jedność między człowiekiem a Bogiem możliwą dzięki Chrystusowi; albo inaczej: złączenie w Chrystusie - w którym zjednoczyły się natury ludzka i Boska ustanawiając „ontologiczny most” między ludźmi a Bogiem - z samym Bogiem. Tym samym soteriologiczne wyzwolenie oznaczało dla nich ostatecznie przebóstwienie człowieka, czyli obdarzenie go właściwościami przynależnymi Bogu ${ }^{14}$. Droga theosis splata się z drogą ku zbawieniu również dlatego, że w pielgrzymce ku przebóstwieniu idą ci, którzy wcześniej ulegli pokusie samoubóstwienia, a zatem potrzebują odkupienia. W każdym razie, próbując odpowiedzieć na powyższe pytania, należy zerkać w stronę Tej, która została „odkupiona w sposób wznioślejszy ze względu na zasługi swego Syna" ${ }^{15}$, i której doskonałe

$13 \quad$ W. C. Kaiser, P. H. Davids, F. F. Bruce, M. T. Brauch, Trudne fragmenty Biblii, tłum. L. Bigaj, T. Fortuna, G. Grygiel, red. wyd. pol. W. Chrostowski, (Prymasowska Seria Biblijna), red. nauk. W. Chrostowski, Warszawa 2011, s. 11.

Por.: D. B.Hart,Chrześcijańska rewolucja azłudzenia ateizmu, tłum. A. Gomola, Kraków 2011, s. 257-258; J. Pelikan, Tradycja chrześcijańska. Historia rozwoju doktryny, tom I: Powstanie wspólnej tradycji (100-600), tłum. M. Höffner, Kraków 2008, s. 242-244.

15 Sobór Watykański II, Konstytucja dogmatyczna o Kościele „Lumen gentium”, nr 53. Korzystam z tłumaczenia: Sobór Watykański II, Konstytucje, dekrety, deklaracje. Tekst polski. Nowe ttumaczenie, Poznań 2002, s. 104-166 [dalej cyt. LG]. 
posłuszeństwo woli Bożej umożliwiło „przedziwną wymianę” w Chrystusie pomiędzy tym, co Boskie i ludzkie. Można powiedzieć, że Matka Boża przez swoje fiat w pewnym sensie „wrodziła” człowieczeństwo Chrystusa w życie osobowe Trójcy Świętej ${ }^{16}$, w ten sposób stając się „Matką przebóstwienia” zarówno naszego, jak i swojego - które już osiągnęła. Jak Pierwsza Ewa uległa pokusie samoubóstwienia, tak Druga Ewa, Niepokalanie Poczęta i cała święta, pozwala dostrzec swoim duchowym synom-pokalańcom, którędy wiedzie stroma ścieżka ku przebóstwieniu, i czym się ono różni od samoubóstwienia.

Właśnie świętość umożliwia z jednej strony pokorne przyjęcie powołania do stania się ,,jak Bóg”, a z drugiej odsunięcie pokusy samoubóstwienia; święci odsłaniają nieco z tajemnicy Bosko-ludzkiego zjednoczenia dokonującego się na wzór zjednoczenia natur w Chrystusie, oraz oświetlają ciemną drogę, którą przeszli - jak przed nimi uczyniła to Druga Ewa, której wędrówka odbywała się przecież także - mówiąc językiem późniejszej mistyki - „ciemną nocą wiary”" Jak zauważa prawosławny teolog, ,jedynie w świętych, którzy doszli, na ile to możliwe na tej ziemi, do szczytu góry świętej, objawia się w pełni to przebóstwienie, jakie Bóg zastrzegł tym, którzy Go miłują"18. Zatem warto zwrócić się do świętych i mistyków Kościoła w poszukiwaniu odpowiedzi na interesujące nas kwestie: chodzić będzie nie tylko o potwierdzenie samej możliwości „bycia jak Bóg” z łaski Bożej oraz wskazanie drogi do tego celu człowiekowi, który przecież Bogiem z natury nie jest i być nie może, ale przede wszystkim o odpowiedź na pytanie, do jakiego stopnia zażyłości z Bogiem został wezwany przez Stwórcę i Zbawiciela człowiek.

\section{Wiedza świętych i mądrość nabyta „bez zmieszania i bez rozdzielania”}

Dogmatyczne refleksje dotyczące przebóstwienia nie stanowią jedynie ,sztuki teologicznej dla sztuki teologicznej”, ale mają znaczenie dla życia chrześcijanina, jeśli ma on rzeczywiście trwać w przebóstwiającej jedności z Bogiem. Ostatecznie, jak zauważał bawarski kardynał,

16 Por. Cz. S. Bartnik, Matka Boża (Biblioteka Katedry Teologii historycznej, 1), Lublin 2012, s. 158.

17 Por. Jan Paweł II, Encyklika Redemptoris Mater (O błogosławionej Maryi Dziewicy w życiu pielgrzymującego Kościoła), nr 17, www.opoka.org.pl [dostęp: 25.09.2014].

18 Por. P. Deseille, Grzech, zbawienie, przebóstwienie. Ujęcie prawosławne, tłum. L. Balter, [w:] Tajemnica odkupienia (Kolekcja Communio, 11), red. L. Balter, Poznań 1997, s. 427. 
chodzi „o nas samych, o odpowiedź na pytanie: W jaki sposób możemy żyć my, ochrzczeni, do których muszą się odnosić słowa Pawła: «Teraz już nie ja żyję, lecz żyje we mnie Chrystus» (Ga 2, 20)"19. Dlatego doktryna musi zostać „,przetłumaczona” na język pobożności, z kolei doświadczenie duchowe pozwoli odkryć pełniej bogactwo kryjące się w tym, co nazywamy przebóstwieniem.

Ten proces przejścia od teorii do praktyki, od doktryny do mistyki, wydarzył się nieprzypadkowo w historii chrześcijaństwa. Jak wskazuje Jaroslav Pelikan, wcześniejsza definicja zbawienia rozumianego jako przebóstwienie została później zinterpretowana jako cel, do którego prowadzi mistyczna droga ${ }^{20}$, w czym wolno chyba widzieć ilustrację związku między prawdami wiary a życiem wierzących, a także wyraz powiązania chrystologii z antropologią wynikający z faktu, że Syn Boży jest współistotny nie tylko Ojcu, ale i ludziom ${ }^{21}$. Przebóstwienie zrealizowane w Chrystusie staje się udziałem człowieka w procesie jego przebóstwienia, eschatologiczną niebieską pełnię zapowiadają pierwociny mistycznego doświadczenia na ziemi. Tak mocno broniący możliwości doświadczenia przebóstwienia już w tym życiu, teolog i święty Kościoła prawosławnego, Grzegorz Palamas (1296-1359), widział w ochrzczonym syna Boga oczekującego usynowienia, odnowionego oczekującego odnowienia, przebóstwionego oczekującego przebóstwienia ${ }^{22}$.

Pomiędzy doktryną (teologią) a duchowością (mistyką) zachodzi bowiem sprzężenie zwrotne wynikające $\mathrm{z}$ ich związku. $Z$ jednej strony teologia pozwala weryfikować oraz ukierunkowuje doświadczenie duchowe, z drugiej sama korzysta z mistycznego poznania i włącza je w swoją refleksję ${ }^{23}$. Ten związek między teologią jako mądrością

$19 \quad$ J.Ratzinger, Kościót. Pielgrzymujaca wspólnota wiary. J. Kard. Ratzingerowi na 75 urodziny - uczniowie, S. O. Horn, V. Pfnür (red.), tłum. W. Szymona, Kraków 2005, s. 71-72.

Por. J. Pelikan, Tradycja chrześcijańska..., dz. cyt., s. 358.

21 Por. Sobór Chalcedoński (451). Definicja wiary, nr 11, [w:] Dokumenty Soborów Powszechnych. Tekst grecki, tacinski, polski. Tom I, Nicea I, Konstantynopol I, Efez, Chalcedon, Konstantynopol II, Konstantynopol III, Nicea II (325-787) (Źródła Myśli Teologicznej, 24), układ i oprac. A. Baron, H. Pietras, Kraków 2007 [dalej cyt. DSP].

22 Por. G.I. Mantzaridis, Przebóstwienie człowieka. Nauka świętego Grzegorza Palamasa w świetle tradycji prawosławnej (Światło Przemienienia, 3), tłum. I. Czaczkowska, Lublin 1997, s. 53 [dalej cyt. PCGP].

23 Warto w tym miejscu podkreślić, że właśnie doświadczenie zbawienie i przebóstwienia stanowiło argument w doktrynalnych sporach (Boskość Syna oraz Ducha) pierwszych wieków. Por. Międzynarodowa Komisja Teologiczna, Wybrane zagadnienia chrystologii (1979), II, A. Korzystam z: Wybrane zagadnienia 
nabytą będącą dziełem rozumu oświeconego przez wiarę a mądrością mistyczną (tzw. wiedzą świętych) będącą darem Ducha Świętego wypływającym ze zjednoczenia z Bogiem i stanowiącą poznanie wyrażane nie pojęciowo ${ }^{24}$ może zostać opisany, jak mniemam, za pomocą „formuły Chalcedonu": synteza obu mądrości musi dokonywać się „bez zmieszania i bez rozdzielania". Na pewno należy je rozróżniać, a to znaczy - cytuję o. prof. Jacka Salija - że „żadnej z tych dwóch form nadprzyrodzonej mądrości nie da się zredukować do drugiej”"25, bo byłby to swego rodzaju „monofizytyzm”. Z drugiej strony nie wolno tego rozróżnienia zamienić w rozdzielenie - w ten sposób popadałoby się w quasi „nestorianizm”.

Nie będzie oczywiście łatwo w praktyce utrzymać tę jedność między teologią a mistyką. Jeśli stosujmy chalcedońskie określenie dla wyjaśnienia tajemniczego związku, nie tyle sprawę wyjaśniamy, ile stawiamy pewnego rodzaju „kamienie graniczne”, poza które nie wolno wychodzić. Warto przypomnieć, że wszystkie określenia Ojców Chalcedonu dotyczące unii hipostatycznej („,bez zmieszania, bez zmiany, bez podzielenia i bez rozłączania”) są negatywne, „przez co zostaje podkreślona tajemnica tego zjednoczenia" oraz zostają odparte niewłaściwe wyjaśnienia tej tajemnicy - pierwsze dwa określenia ,skierowane są przeciwko radykalnym tendencjom monofizytów; ostatnie zaś dwa - przeciwko tendencjom nestoriańskim"26.

W każdym razie rozdzielenia mistyki i dogmatyki musi unikać nie tylko wspólnota Kościoła, ale i pojedynczy teolog, od którego wymaga się egzystencjalnego zaangażowania (sequela Christi) oraz trwania w miłości (por. $1 \mathrm{~J} \mathrm{4,8),} \mathrm{bez} \mathrm{których} \mathrm{nie} \mathrm{można} \mathrm{uprawiać} \mathrm{teologii}{ }^{27}$.

chrystologii (1979), tłum. J. Bielecki, [w:] Od wiary do teologii. Dokumenty Międzynarodowej Komisji Teologicznej 1969-1996, J. Królikowski (red.), Kraków 2000, s. 111-132. Por. również: J. Meyendorff, Teologia bizantyjska. Historia $i$ doktryna, tłum. J. Prokopiuk, Kraków 2007, s. 18.

Por. Międzynarodowa Komisja Teologiczna, Teologia dzisiaj. Perspektywy, zasady $i$ kryteria, tłum. K. Stopa, Kraków 2012, nr 91-92. Por. tamże, nr 99, gdzie jest mowa o tym, iż teologia „uznaje całkowite pierwszeństwo Boga; chce nie tyle posiąść Boga, ile być przez Niego posiadaną. Musi zatem zwracać uwagę na to, co Duch mówi do Kościołów przez «wiedzę świętych»".

Por. J. Salij, Madrościowy wymiar teologii, [w:] O naturze teologii (Studia theologiae fundamentalis, 5), B. Kochaniewicz (red.), Poznań 2013, s. 55.

DSP, s. 223, przypis 72e.

Por. J. Szymik, Theologia Benedicta. Tom I, Katowice 2010, s. 65-68 i 127. Dlatego Ojcowie Kościoła wiązali zawsze teologię z modlitwą, która „otwiera, przenika i kończy ich myślenie o wierze" (M. Fiedorowicz, Teologia ojców Kościoła. Podstawy wczesnochrześcijańskiej refleksji nad wiara, tłum. W. Szymona, Kraków 2009, s. 452). 
Hans Urs von Balthasar wskazywał na nieodzowny związek teologii ze świętością wynikający z samej natury teologii - która jako włączona w posłanie do przepowiadania wymaga wcześniejszego uświęcenia ${ }^{28}$, dlatego „każdy, kto się zalicza do Kościoła Chrystusowego, musi - na swój szczególny sposób - być jednocześnie świętym i świadkiem”"29. Między wspólnotą wierzących a teologiem zachodzi symbioza, którą ks. Tadeusz Dzidek tłumaczy następująco:

Wspólnota ożywia wiarę teologa, nieustannie stawia go przed osobowym Panem. W ten sposób teolog zabezpieczony jest przed redukowaniem swojej relacji do Boga jedynie do intelektu. $Z$ kolei bycie przed Panem, angażujące całą osobowość, oddziałuje na jakość uprawianej przez niego teologii - jej celem jest nie tylko poznanie, ale także mistyczne zjednoczenie. Stanowiąc owoc intelektualnych poszukiwań, staje się ona dla wspólnoty światłem i umocnieniem w bardzo trudnej duchowej wspinaczce ${ }^{30}$.

Ksiądz Robert J. Woźniak widzi w złotym wieku mistyki hiszpańskiej wartość teologiczną, która pojawiła się w czasie, gdy teologia uniwersytecka stawała się coraz bardziej naukowa i oddzielona od wiary Kościoła ${ }^{31}$, co również mogłoby dowodzić konieczności jednoczenia mistyki i teologii zamiast ich rozdzielania. W każdym razie mistyczne doświadczenia poddają się „wcieleniu” w aparat filozoficzno-teologiczny służący ich opisowi. W przypadku Jana od Krzyża (1542-1591) można mówić o mistyce zawierającej tradycję Kościoła z jednej strony, oraz o doświadczeniu duchowym wpisanym w ramy filozofii scholastycznej z drugiej strony ${ }^{32}$. Doświadczenia mistyczne stanowią pierwociny życia wiecznego, a zatem wolno na ich podstawie snuć refleksje dotyczące przyszłości człowieka w Bogu. Doktor Mistyczny właśnie w przeżywanym już na ziemi doświadczeniu zjednoczenia z Bogiem widział przedsmak życia niebieskiego ${ }^{33}$. Według Jana Pawła II od kar-

28

Por. H. U. von Balthasar, Teologia a świętość, tłum. M. Serzycki, [w:] Podstawy wiary - teologia (Kolekcja Communio, 6), red. L. Balter, Poznań 1991, s. 424.

Tamże, s. 427. I dalej: „Tam, gdzie nauka, która określa się jako teologia, przestaje być następstwem apostolskiego świadectwa, a tym samym posłannictwa Jezusowego i związanej z nim świętości, przestaje być także miarodajna dla wiary Kościoła" (tamże, s. 430).

T. Dzidek, Granice rozumu w teologicznym poznaniu Boga, Kraków 2001, s. 344345 [dalej cyt. GR].

31 Por. R. J. Woźniak, Przyszłość, teologia, społeczeństwo (Myśl Teologiczna, 56), Kraków 2007, s. 103.

Por. GR, s. 355.

Por. np. JKD, s. 722. 
melity, w którego nauczaniu łączą się doktryna z pełnią życia, mogą wiele nauczyć się również teologowie powołani do łączenia naukowych poszukiwań z modlitwą ${ }^{34}$.

\section{Przebóstwienie według świętych i mistyków}

\section{Dusza Bogiem z Boga przez uczestnictwo w Bogu (św. Jan od Krzyża)}

Fundamentem przebóstwienia są sakramenty (zwłaszcza Chrzest i Eucharystia) dostępne w Kościele - „wspólnocie przebóstwienia” (używając określenia Palamasa) ${ }^{35}$, dzięki którym wierzący przez Ducha Świętego zostaje wezwany do mistycznego zjednoczenia z Bogiem (zwanego „zjednoczeniem przemieniającym” albo „zjednoczeniem przekształcającym”36, inaczej „małżeństwem duchowym”), kiedy to, jak zauważa dokonujący w swojej pracy syntezy teologii dogmatycznej z mistyczną o. Réginald Garrigou-Lagrange, „mimo nieskończonej odległości, dzielącej byt stworzenia od Bytu Stwórcy (...) dusza jest przebóstwiona przez otrzymanie doskonałego uczestnictwa w naturze Bożej. W tym znaczeniu św. Paweł mógł napisać: «Kto łączy się z Panem, jest z Nim jednym duchem» (1 Kor 6, 17)"37. Środkiem prowadzącym do tak wzniosłego celu, jakim jest przebóstwienie, są według św. Jana od Krzyża cnoty teologalne (wiara, nadzieja, miłość).

Wolno widzieć przebóstwienie jako centralną kwestię spuścizny hiszpańskiego mistyka, której poświęcił zwłaszcza dwa dzieła: Pieśn duchowa i Żywy ptomień miłości ${ }^{38}$. W pierwszym z nich ${ }^{39}$ Święty pisze, że Bóg pragnie wywyższenia duszy przez zrównanie jej z sobą, co dokonuje się dzięki miłości, ponieważ właśnie miłości właściwością jest zrównanie miłujących się osób. Oblubieńcza miłość między duszą

$34 \quad$ Por. Jan Paweł II, List apostolski „Św. Jan od Krzyża, mistrz w wierze”, nr 17. Korzystam z tłumaczenia [w:] JKD, s. 5-21.

Por. PCGP, s. 62.

Jan od Krzyża rzadko używa pojęcia „przebóstwienie” (endiosamiento), woli posługiwać się innymi, korzysta zwłaszcza z terminów unión i transformación (,zjednoczenie przekształcające”)-por.: O. Filek, Wprowadzenie,[w:]JKD, s. 40; M. Chmielewski, Przebóstwienie człowieka wedtug świętego Jana od Krzyża, „Ateneum Kapłańskie” (1991) nr 117, s. 54 [dalej cyt. PCJK].

37 R. Garrigou-Lagrange, Trzy okresy życia wewnętrznego wstępem do życia $w$ niebie, tłum. T. Landy, Niepokalanów 2001, s. 840-841.

Por. PCJK, s. 54.

Korzystam z wydania: Św. Jan od Krzyża, Pieśń duchowa, [w:] JKD, s. 521-714. 
a Bogiem sprawia, iż wszystkie rzeczy stają się im wspólne ${ }^{40}$, a zespolenie ich jest tak mocne, że przemienia duszę i czyni ich jednym

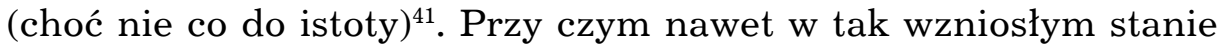
„przeobrażenia” dusza pragnie kochać Boga jeszcze bardziej, miłością taką, jaką On umiłował duszę, dlatego oczekuje zrównania z Bożą miłością w wiecznej chwale. Wtedy to będzie - mówiąc językiem Apostoła Narodów - poznawała Boga tak, jak On ją poznał (por. 1 Kor 13, 12), a zatem będzie Go również tak miłowała, jak została umiłowana przez $\mathrm{Niego}^{42}$. Nawet jednak wtedy nie zaniknie wola duszy, gdy „dwie wole połączą się w jednej woli i w jednej tylko miłości Boga”, a dusza będzie miłowała „Boga mocą i wolą samego Boga, będąc z Nim zjednoczona tą samą potęgą miłości, jaką Bóg ją kocha" ${ }^{43}$, bo warunkiem tego jest, by dusza dała Bogu swoją zgodę (wola!).

Jak dusza może kochać Boga nie swoją, a Boską mocą? Miłość duszy zostaje według Doktora Kościoła spotęgowana przez Ducha Świętego, który sprawi, „że dusza ukocha Go z taką siłą miłości, jak On ją kocha" ${ }^{44}$. Bóg dając duszy Ducha Świętego „tchnie” w nią również zdolność do tego, by sama mogła tchnąć w Boga to tchnienie miłości, „jakie Ojciec tchnie w Syna, Syn w Ojca, a którym jest sam Duch Święty", owszem już teraz, choć nie tak wyraźnie jak w życiu wiecznym, dusza ,zjednoczona i przeobrażona w Boga, tchnie w Bogu do Boga to samo tchnienie Boskie, jak i sam Bóg tchnie w samym sobie w nią będącą w Nim przeobrażoną". Święty, świadomy możliwości zgorszenia nowiną tak dobrą, że aż trudną do przyjęcia, zaraz dodaje:

I nie ma powodu sądzić, że jest to niemożliwe, by dusza mogła dojść do czegoś tak wzniosłego, aby przez uczestnictwo mogła tchnąć w Bogu, jak Bóg tchnie w niej. Gdy bowiem Bóg udzieli jej łaski zjednoczenia w Trójcy Przenajświętszej, tym samym dusza staje się przebóstwiona i samym Bogiem przez uczestnictwo ${ }^{45}$.

40 Por. JKD, s. 659.

$41 \quad$ Por. JKD, s. 673.

42 Por. JKD, s. 700. Według Doktora Mistycznego istnieje następujący związek pomiędzy miłością a widzeniem Boga. Otóż miłość opiera się na woli, której właściwością jest dawać, a nie brać; z kolei rozum w niebie otrzyma przywilej widzenia samej istoty Boga, bo jego właściwością jest otrzymywać; bez doskonałego widzenia Boga nie można oczekiwać doskonałego miłowania Go. Tak więc wola chcąca dawać miłuje Boga, a rozum przyjmuje dary Boże (por. JKD, s. 701-702).

43 JKD, s. 700.

44 Tamże, s. 701.

45 Tamże, s. 705. 
W nawiązaniu do 2 P 1, 2-4 Święty tłumaczy, że dusze posiadają „przez uczestnictwo” wszystkie dobra, które Syn Boży ma z natury, wolno więc powiedzieć, że są równe Bogu i Bogami przez uczestnictwo $^{46}$. W słowach Apostoła Piotra można według Jana od Krzyża wyczytać, że „dusza będzie uczestniczyła w samym Bogu i będzie czyniła w Nim i wspólnie z Nim dzieło całej Trójcy Świętej (...) właśnie na skutek zjednoczenia substancjalnego między duszą a Bogiem" ${ }^{47}$. W Żywym płomieniu miłości $i^{48}$ mistyk tłumaczy, na czym to zjednoczenie polega. To Duch Święty przenika do głębi oczyszczoną substancję duszy $^{49}$ i jej oczyszczone władze (rozum, pamięć i wolę), a skutkiem tego Bosko-ludzkiego zetknięcia jest właśnie substancjalne zjednoczenie $^{50}$, w którym to spotkaniu „Bóg przenika samą substancję duszy, przebóstwiając ją przez całkowite pochłonięcie jej w swój byt" ${ }^{51}$. Już w stanie zaślubin duchowych substancja Boża dotyka substancji duszy, co daje pewne poznanie życia wiecznego ${ }^{52}$. Dusza umarła dla samej siebie, a żyje tym, czym żyje Bóg (hiszpański święty nawiązuje do Ga $2,20)$, i w ten sposób dusza staje się Bogiem, bo jej władze stają się Boskie: rozum duszy staje się „rozumem Bożym, jej wola jest wolą Bożą, jej pamięć jest wieczystą pamięcią Bożą”. Oczywiście „substancja tej duszy nie jest wprawdzie substancją Boga, gdyż dusza nie może substancjalnie przemienić się w Niego, jednak będąc z Nim tak ściśle jak tutaj złączona i tak pochłonięta przez Niego, jest Bogiem przez uczestnictwo w Bogu”53, albo inaczej: „dusza stała się Bogiem z Boga przez uczestnictwo w Nim i w Jego przymiotach" ${ }^{\text {, }}$, zasłużyła na „zjednoczenie się z Bogiem i substancjalne przeobrażenie we wszystkich swych władzach"55. Tak tę naturę „przeobrażenia mistycznego” komentuje ks. Marek Chmielewski:

46 Por. JKD, s. 706.

47 Tamże, s. 707.

48 Korzystam z wydania: Św. Jan od Krzyża, Żywy płomień miłości, [w:] JKD, s. 715-803.

49 Por. JKD, s. 726. Substancją duszy nazywa mistyk szczyt czy centrum duszy, w którym człowiek doświadcza bezpośrednio Boga - por. PCJK, s. 55.

$50 \quad$ Por. JKD, s. 728.

$51 \quad$ Tamże, s. 738

52 Por. tamże, s. 747-748.

$53 \quad$ Tamże, s. 755

54 Tamże, s. 761.

$55 \quad$ Tamże, s. 769 
Z filozoficznego punktu widzenia przebóstwienie dotyczy tylko aspektów akcydentalnych. Polega więc na zmianie formy bytowania, a nie na zmianie substancjalnej, co groziłoby panteizmem, który został stanowczo potępiony przez Kościól. Przebóstwienie nie jest także anihilacją, ontologicznym zatracaniem własnej tożsamości, roztopieniem się bytu ludzkiego w Bycie Bożym, ani jedynie intelektualnym oglądem Jedności Bóstwa w jego aspektach filozoficznych. Św. Jan od Krzyża wyraźnie podkreśla dystynkcję i nieidentyczność substancji... ${ }^{56}$.

Wolno jednak zapytać, na ile doświadczenie naszego Mistyka w swoim opisie zostało jednak poddane „kontroli”, jaką zapewniło mu jego teologiczno-filozoficzne wykształcenie? Czy bez ortodoksyjnych „uprzedzeń" odczytany opis mistycznego przeobrażenia nie sprawia jednak wrażenia „substancjalnego monofizytyzmu”, przed którym Święty broni się być może jedynie (aż) ze względu na świadomość potępienia przez Kościół panteizmu? Wydaje mi się, że na tak postawione pytanie należałoby odpowiedzieć pytaniem: czy zjednoczenie dwóch różnych substancji musi być czymś mniejszym od zjednoczenia dwóch natur Boskiej i ludzkiej w Chrystusie? Jak sądzę, scheda po Doktorze Mistycznym pozwala odpowiedzieć przecząco: nie musi, owszem wolno mówić o tak samo ścisłym połączeniu tego, co Boskie i ludzkie w relacji człowieka z Bogiem ${ }^{57}$. Nie znaczy to jednak, że każdy mieszkaniec nieba będzie równie ściśle zjednoczony z Bogiem; w nawiązaniu do Jezusowego „w domu Ojca mego jest mieszkań wiele” (por. J 14, 2) Święty mówi o stopniach miłości i odpowiadających im stopniach ścisłości zjednoczenia z Bogiem ${ }^{58}$. Interesuje mnie jednak pytanie o mieszkanie w możliwie najbliższym „sąsiedztwie” Boga o bycie domownikiem Jego samego (por. Ef 2, 19).

Dzięki przeobrażeniu dusza może według Mistyka działać w Bogu przez Boga to wszystko, co On sam działa w duszy, bo dzięki jedności woli duszy i Boga ich działanie jest również jedno. Wzajemna miłość przejawia się w czynnej wymianie wspólnego dobra (por. J 17, 10) obojga: Bóg daje się duszy „na własność”, a dusza składa Bogu równie wielki (nieskończony) dar - bo daje Boga w Bogu ${ }^{59}$. Jest to doskonała miłość, bo „dusza kocha Boga nie przez samą siebie, lecz przez (...) Ducha Świętego, tak jak Ojciec i Syn się kochają"60, co według Jana od Krzyża odpowiada słowom Jezusa: „Aby miłość, którą mnie

\begin{tabular}{ll}
\hline 56 & PCJK, s. 57. \\
57 & Por. JKD, s. 632. \\
58 & Por. tamże, s. 725. \\
59 & Por. tamże, s. 792-793. \\
60 & Tamże, s. 794
\end{tabular}


umiłowałeś, w nich była, i ja w nich” ( $\mathrm{J}$ 17, 26). Formą ,zjednoczenie przebóstwiającego - pisze jeden z komentatorów dziedzictwa świętego - jest tzw. małżeństwo duchowe, zaś środkiem tzw. dotyki mistyczne"61 dwóch rodzajów (dotyki substancjalne, gdy substancja Boga dotyka substancji duszy, oraz dotyki przymiotów Bożych odnoszące się do władz duszy), które dynamizują miłość nadprzyrodzoną ${ }^{62}$. Żywy płomień miłości kończy się obrazem biblijnego łona - a więc samej substancji duszy, w której doświadcza ona miłosnego zjednoczenia z Bogiem ${ }^{63}$. W języku obrazowo-symbolicznym Doktor Mistyczny ukazuje najgłębsze z możliwych zjednoczenie człowieka z przenikającym go Bogiem, ,przy czym tożsamość człowieka zostaje zachowana, a zarazem przekroczona jego odrębność, to znaczy - nie da się rozdzielić Boga i stworzenia, choć pozostaje rozróżnienie między stworzeniem i Stwórcą" ${ }^{64}$. Oto mistyczno-eschatologiczny Chalcedon.

\section{„Jakby unia hipostatyczna” między człowiekiem a Bogiem (św. Maksymilian)}

Kolbiańskie intuicje wpisują się w coś, co można by nazwać „duchową zasadą akcji-reakcji”"65, która z kolei zdaje się dobrze odpowiadać „symetryczności” uchwyconej przez św. Atanazego. Reakcją na akcję Wcielenia będzie przebóstwienie: ludzie zjednoczeni z Bogoczłowiekiem i upodobnieni do niego stają się, można sparafrazować św. Maksymiliana Kolbe (1894-1941), człowiekobogami. Przy czym zjednoczeniu temu Święty wydaje się nie wyznaczać żadnych granic:

Więc Bóg może być tylko celem naszym. Poznać, pokochać, posiąść Boga, zjednoczyć się z Nim, zamienić niejako w Niego, ubóstwić, stać się jakby Bogiem-Człowiekiem. (...) Na wzór tego pierwszego Syna Bożego, Boga-Człowieka, nieskończonego mają się urabiać odtąd dzieci Boże; kopiując rysy Boga-Człowieka, naśladując Chrystusa Pana, będą dążyć do świętości dusze; im kto dokładniej odtworzy w sobie obraz Chrystusa Pana, tym bardziej zbliży się do Bóstwa, ubóstwi, stanie człowiekiem-Bogiem. (Zaślubiny duszy z Chrystusem dla upodobnienia i działania Boskiego). (...) A jak Go posiąść, jak się z tym szczęściem

$61 \quad$ PCJK, s. 61.

62 Por. tamże, s. 62.

63 Por. JKD, s. 799-801.

64 GR, s. 360 .

65 W poniższym podpunkcie artykułu korzystałem z wcześniejszych refleksji opublikowanych w książce: S. Zatwardnicki, Pomoc przeciw nieprzyjaciotom Twoim, czyli jak chwalić Maryję i bronić Jej godności, Kraków 2014, s. 366-374 oraz 401-409. 
zjednoczyć? Jak najdoskonalej. I tu bez granic. Stać się z Nim jedno, aż Nim - Bogiem ${ }^{66}$.

Jak wiadomo, gorącą czcią darzył założyciel Rycerstwa Niepokalanej oczywiście Maryję. Z tym związana jest kolejna intuicja teologiczno-mistyczna, którą warto wziąć pod uwagę w teologii. Otóż Kolbe widzi zjednoczenie Matki Bożej z Duchem Świętym tak głębokie, że nie waha się na jego wyrażenie użyć z pozoru heterodoksyjnych określeń (w istocie być może chroniących jednak ortodoksyjny sens). „Niepokalana jest - pisał Maksymilian - jakby Duchem Świętym wcielonym. W Ojcu jest jedna osoba i jedna natura. W Jezusie Chrystusie jest jedna osoba, a dwie natury. W Niepokalanej - dwie osoby i dwie natury, lecz jako najściślej zjednoczone" ${ }^{67}$. Tak chyba należy czytać tę logikę: celem misji Wcielenia może być tylko tak samo intensywne zjednoczenie człowieka z Bogiem, z jakim złączyły się dwie natury Chrystusa w jednej Osobie Syna Bożego. A więc coś tak głębokiego, że można by mówić o „pewnego rodzaju unii hipostatycznej Maryi i Ducha Świętego”, a chociaż „Maryja nie jest hipostatycznie zjednoczona z Parakletem, jest Ona bowiem osobą ludzką, osobą stworzoną, a nie wcieleniem trzeciej Osoby Trójcy"68, to jednak akcji odpowiadać musi adekwatna reakcja: „W Jezusie dwie natury, Boska i ludzka, a osoba jedna - Boska, a tu i dwie natury, i dwie jeszcze osoby Ducha Przenajświętszego i Niepokalanej, ale zjednoczenie Bóstwa z człowieczeństwem przechodzi wszelkie pojęcie" ${ }^{69}$. To ścisłe zjednoczenie realizuje się z poszanowaniem odrębności osobowej Boga i człowieka, a więc - przyznaje Kolbe - inaczej „niż w zjednoczeniu hipostatycznym dwóch natur Boskiej i ludzkiej w jednej Osobie Chrystusa. To jednak w niczym nie przeszkadza, by działalność Maryi była najdoskonalszą działalnością Ducha Świętego" ". Jednak pomimo tego związek Maryi z Bogiem jest tak ścisły, że zakonnik pyta: „Czyż nie jest Ona jakoby częścią Trójcy Przenajświętszej?" 71 , albo - w innym miejscu, już nie pytająco, ale twierdząco pisze o Niej, że „wpleciona w miłość Trójcy

66 M. M. Kolbe, Pisma. Cz. II, przygot. do dr. P. Sotowski, Niepokalanów 2008, s. 721.722.723 [dalej cyt. MMK].

$67 \quad$ MMK, s. 615.

R. Laurentin, Nieznany Duch Święty. Odkrywanie Jego doświadczenia i Jego Osoby, tłum. M. Tarnowska, Kraków 1998,, s. 477.

69 MMK, s. 665.

70 Tamże, s. 629.

71 Tamże, s. 165. 
Przenajświętszej staje się od pierwszej chwili istnienia na zawsze, na wieki dopełnieniem Trójcy Przenajświętszej"72.

Według Kolbego podstawą zjednoczenia Matki z Synem ${ }^{73}$ i fundamentem Wcielenia jest właśnie zjednoczenie Maryi z Duchem Świę$\operatorname{tym}^{74}$. Z kolei Wcielenie ustanawia fundament ontologiczny przebóstwienia, które nie byłoby możliwe bez unii hipostatycznej. Mimo że krzewiciel Militia Immaculate podkreśla wyjątkową wielkość Maryi, to jednak pośrednio wskazuje tym samym na regułę obowiązującą wszystkich chrześcijan: bo tylko wtedy Matka Kościoła będzie najbliżej nie tylko Chrystusa, ale i wierzących ${ }^{75}$, jeśli Jej zjednoczenie z Bogiem ma związek z powołaniem Jej duchowych synów. Natura ludzka okazuje się zdolna do tak głębokiego zjednoczenia z Bogiem, że ten może stać się uczestnikiem natury Boskiej (por. 2 P 1, 4), czy też - mówiąc językiem personalisty - przebóstwienie można widzieć jako „wosobienie” osoby człowieka w Osoby Boskie ${ }^{76}$, albo jako istnienie człowieka i Boga jeden w drugim, jak w przypadku Wniebowziętej ${ }^{77}$, na zasadzie swego rodzaju ,perychorezy eschatologicznej”78. Przywołując na chwilę św. Jana od Krzyża, można by powiedzieć: „Nie byłoby

72 Tamże, s. 684.

73 Według ks. Czesława Bartnika „Maryja to misterium tak ściśle zespolone z Jezusem Chrystusem, że trzeba mówić o jedności, niemal na podobieństwo jedności osobowej między człowieczeństwem i bóstwem w Jezusie Chrystusie” - Cz. S. Bartnik, Matka Boża..., dz. cyt., s. 190.

Por. MMK, s. 684. Św. Jan od Krzyża uważa, że do duszy Maryi „nie przeniknęła żadna forma jakiegoś stworzenia i nigdy nią nie powodowała. Jej poruszenia pochodziły zawsze z Ducha Świętego" (JKD, s. 313).

Por. LG 54.

Por. Cz. S. Bartnik, Dogmatyka katolicka. Tom I, Traktaty I-VI, Lublin 2012, s. 753.

Por. J. Ratzinger, Wzniosła Córa Syjonu. Rozważania mariologiczne, tłum. J. Królikowski, Poznań 2002, s. 138: „Jego miłość czyni nas nieśmiertelnymi i tę miłość przynoszącą nieśmiertelność nazywamy «niebem». Niebo nie jest niczym innym niż to: Bóg jest wystarczająco wielki, by mieć miejsce także dla nas, nędznych istot. Człowiek Jezus, który równocześnie jest Bogiem, jest dla nas nieskończoną gwarancją, że istota-człowiek i Istota-Bóg mogą istnieć i żyć wiecznie jeden w drugim. Myślę, że jeśli uznało się coś takiego, to do pewnego stopnia uznaje się także to, co wyraża dziwne określenie «cielesne wniebowzięcie»".

78 Por. R.J.Woźniak, Przyszłość, teologia, społeczeństwo, dz.cyt., s. 113. Por. tamże, s. 11-12: „Tajemnica wejścia Boga w historię jest zapowiedzią i obietnicą wejścia człowieka z życie wieczne, jakim jest trynitarna perychoreza życia i miłości w wolności”. 
to bowiem prawdziwe i całkowite przeobrażenie, gdyby się dusza nie przeobraziła w trzy osoby Trójcy Przenajświętszej..."79.

Uwzględniając rolę Maryi współpracującej w historii zbawienia realizowanej przez Drugiego Adama, można by uzupełnić paralele antytetyczne Ojców Kościoła ${ }^{80}$ i powiedzieć, że Druga Ewa staje się przyczyną przebóstwienia rodzaju ludzkiego, w przeciwieństwie do Ewy pierwszej, która uległa pokusie samoubóstwienia. Za Ojcami Soborowymi możemy widzieć w Matce Bożej pierwociny przyszłości wszystkich wierzących: „w niebie Matka Jezusa doznaje już chwały co do ciała i duszy, będąc obrazem i początkiem Kościoła mającego osiągnąć pełnię w przyszłym wieku" ". Daje tu o sobie znać Boska logika trafnie „wychwycona” przez św. Maksymiliana: to, co dokonało się we wcielonej Osobie Boskiej, musi znaleźć kontynuację w osobach ludzkich ${ }^{82}$.

\section{Ścisłe zjednoczenie woli ludzkiej z wolą Bożą (św. Faustyna)}

W sformułowaniach III Soboru Konstantynopolitańskiego (680681) należy widzieć konieczne uzupełnienie Soboru w Chalcedonie: soborowa definicja mówiąc o zjednoczeniu natur Boskiej i ludzkiej nie odpowiedziała na pytanie, w jaki sposób „praktycznie” (czy raczej „egzystencjalnie") to zjednoczenie się dokonało w życiu Chrystusa. Jeśli modelem przebóstwienia człowieka jest unia hipostatyczna, potrzeba było ją „,rozszyfrować” na tyle, by z chrystologii wypływały wnioski antropologiczne. Otóż chalcedońskim „,bez zmieszania i bez rozdzielania” Ojcowie Soboru z VII wieku obejmują zjednoczenie się woli ludzkiej i Boskiej, wskazując tym samym, że droga przebóstwienia człowieka

79 JKD, s. 705.

80 Por. F. Drączkowski, Patrologia, Pelplin - Lublin 2007, s. 70.108-109.

81 LG 68

82

Por. Bóg żywy. Katechizm Kościoła Prawostawnego..., dz. cyt., s. 468. Por. również: E. Ozorowski, Humanitas unii hipostatycznej, [w:] Człowieczeństwo Boga, A. Proniewski, A. Dębski (red.), Białystok 2013, s. 19: „Człowieczeństwo Jezusa Chrystusa jest szczęściem ludzi (...). Szczęście to jednak zostaje osiągnięte definitywnie w Zmartwychwstaniu. W Jezusie Chrystusie natura ludzka, poczęta we Wcieleniu, zostaje przebóstwiona w Zmartwychwstaniu. W człowieku, przyjmującym chrzest, rodzi się nowe życie, które zostanie przebóstwione w pełni w powszechnym zmartwychwstaniu. Cel ten jest teraz przed ludźmi. Doszedł do niego Chrystus, osiągnęła go również Maryja jako Wniebowzięta. Ludzie natomiast, zanurzeni przez chrzest w śmierci Chrystusa, wkraczają w nowe życie, dążące do pełni w zmartwychwstaniu (Rz 6, 4-7). Już mają oni dostęp do uczestnictwa w Boskiej naturze (2 P 1,4), ale w pełni jeszcze w niej nie uczestniczą". 
wiodła będzie właśnie przez poddanie woli człowieka woli Bożej. Z tej perspektywy warto usłyszeć Maryjne fiat - nie jednorazowe, ale wyrażające postawę całego życia. Echem tego „tak” będzie pełnienie woli Bożej przez każdego wierzącego, a mistyczne doświadczenia stanowić mogą potwierdzenie, do czego takie uzgadnianie woli prowadzi.

Mistycy i święci - wolno sformułować na bazie ich doświadczeń taki wniosek - zawsze upatrują właśnie w pełnieniu Bożej woli najlepszego czy jedynego sposobu upodobnienia się do Boga i zjednoczenia z Nim. Właśnie dzięki takiemu wynikającemu z miłości poddaniu woli Bożej, św. Faustyna, ,jedna z największych mistyczek w dziejach - pisze autorka jej biografii - prowadzona przez Pana dojdzie do szczytów miłosnego zjednoczenia duszy z Bogiem. Ukoronowaniem tego będzie poprzedzony duchowymi zrękowinami akt zaślubin serc, w którym dostąpi zaślubienia duszy z Bogiem w sposób najpełniejszy z możliwych na ziemi”"83, kiedy to dostąpi „przebóstwiającego zjednoczenia duszy z Bogiem, które odtąd będzie już stałe" ${ }^{84}$. Święta Faustyna Kowalska (1905-1938) w swoim Dzienniczku daje wielokrotnie wyraz temu przekonaniu, że jej poufałe obcowanie z Bogiem wynika właśnie z dobrowolnie podjętej współpracy z Bogiem, którego wolę pełni:

Jezus pochylił się do mnie i spojrzał łaskawie, i mówił mi o woli Ojca niebieskiego. Mówił mi, że ta dusza jest najdoskonalsza i święta, która pełni wolę Ojca Mojego, ale niewiele jest takich dusz. [Ze] szczególną miłością patrzy na duszę, która żyje wolą Jego, i powiedział mi Jezus, że ja w doskonały sposób, czyli doskonale, pełnię wolę Bożą i - „dlatego w tak szczególny i ścisły sposób łączę się z tobą i obcuję" ${ }^{85}$.

Dziś na medytacji dał mi Bóg wewnętrzne światło i zrozumienie świętości, i na czym ona polega (...). Ani łaski, ani objawienia, ani zachwyty, ani żadne dary jej udzielane nie czynią ją doskonała, ale wewnętrzne zjednoczenie duszy mojej z Bogiem (...). Świętość i doskonałość moja polega

$83 \quad$ E. K. Czaczkowska, Siostra Faustyna. Biografia Świętej, Kraków 2012, s. 86 [dalej cyt. SF].

84 SF, s. 98-99.

Św. Siostra Faustyna Kowalska, Dzienniczek. Miłosierdzie Boże $w$ duszy mojej, Kraków, [br], nr 603 [dalej cyt. Dz]. Por. tamże, nr 666: „Zrozumiałam, że wszelka dążność do doskonałości i cała świętość jest [osadzona] na wypełnianiu woli Bożej. Doskonałe spełnienie woli Bożej jest dojrzałością w świętości, tu na wątpliwości nie ma miejsca”. Również św. Jan od Krzyża widział w poddaniu się woli Bożej drogę do mistycznego zjednoczenia z Bogiem, o czym pisał w Drodze na Górę Karmel: „Stan zjednoczenia z Bogiem polega na tak całkowitej przemianie duszy w wolę Bożą, by w niej nie było nic przeciwnego woli Bożej, ale żeby we wszystkim i w każdym poruszeniu wola jej była wolą Bożą" (JKD, s. 174). 
na ścisłym zjednoczeniu woli mojej z wolą Bożą. Bóg nigdy nie zadaje gwałtu naszej wolnej woli. Od nas zależy, czy chcemy przyjąć łaskę Bożą, czy nie; czy będziemy z nią współpracować, czy też ją zmarnujemy ${ }^{86}$.

Tym cenniejsze świadectwo pozostawiła nam zakonnica, że powstało ono na bazie doświadczenia mistycznego (praktyka), a nie teorii mistyki, której Kowalska nie znała - chyba jedynie z nauk kierowników duchowych. Właśnie dzięki brakom wiedzy teoretycznej oraz nieuczonemu językowi spuścizna Świętej nabiera wyjątkowej wartości ${ }^{87}$. Sekretarka Bożego Miłosierdzia pisała o przemienieniu w Chrystusa ${ }^{88}$, o duszach na wskroś przebóstwionych ${ }^{89}$, o niepojętej miłości Boga wywyższającej człowieka aż do Bóstwa (por. Dz 1172). Modliła się o swoje przebóstwienie: „Jezu mój, przeniknij mnie całą, abym mogła Cię odzwierciedlić w całym życiu swoim. Przebóstwij mnie, aby czyny moje miały wartość nadprzyrodzoną"90, a jego źródła upatrywała w Eucharystii: „Najsłodszy Jezu, rozpal moją miłość ku sobie i przemień mnie w siebie, przebóstwij mnie, aby czyny moje miłe Ci były, niech to sprawi moc Komunii świętej, którą codziennie przyjmuję. Jak bardzo pragnę być przeistoczona całkowicie w Ciebie, o Panie" ${ }^{91}$.

Właśnie wspomniany związek przebóstwienia z Eucharystią (czy szerzej: sakramentami) doświadczany w życiu mistycznym jest ciekawy i nośny teologicznie. Teologia wschodnia zwraca uwagę na uczestnictwo człowieka w naturze Bożej, które urzeczywistnia się właśnie przez Eucharystię oraz inne sakramenty, w których działa Duch Święty. Kongregacja Nauki Wiary w liście poświęconym medytacji chrześcijańskiej podkreśliła działanie Chrystusa w sakramentach, zwłaszcza w Eucharystii, w której dokonuje się „przedziwna wymiana” - cytuję: „Chrystus daje nam siebie, czyniąc nas uczestnikami swojej Boskiej natury, bez naruszania natury stworzenia, w której On sam uczestniczy przez Wcielenie" ${ }^{92}$. Papież Benedykt XVI widział w Eucharystii swego rodzaju „nuklearne rozszczepienie” wnoszące do najskrytszego wnętrza człowieka radykalną przemianę, od której rozpoczyna się proces

\begin{tabular}{ll}
\hline 86 & Dz 1107. \\
87 & Por. SF, s. 87. \\
${ }_{88}$ & Por. Dz 1140. \\
89 & Por. tamże 180. \\
${ }_{90}$ & Tamże 1242. \\
${ }_{91}$ & Tamże 1289.
\end{tabular}

92 Kongregacja Nauki Wiary, List do biskupów Kościoła katolickiego o niektórych aspektach medytacji chrześcijańskiej „Orationis formas”, nr 14 [dalej cyt. OF]. Korzystam z wydania: W trosce o petnię wiary. Dokumenty Kongregacji Nauki Wiary 1966-1994, J. Królikowski, Z. Zimowski (red.), Tarnów 2010, s. 407-424. 
przebóstwienia całej rzeczywistości, czyli doprowadzenia jej do stanu, w którym Bóg stanie się wszystkim we wszystkich (por. 1 Kor 15, 26$)^{93}$.

$\mathrm{Z}$ jeszcze jednego powodu warto teologom sięgać po Dzienniczek: otóż jego autorka, która nie ukończyła nawet trzech klas szkoły podstawowej, tym się wyróżnia na tle innych świętych, że prezentuje oryginalne i brzemienne teologicznie doświadczenia mistyczne, wśród których warto w interesującej nas kwestii wspomnieć na związek Wcielenia i Zbawczej Męki jako największych przejawów miłosierdzia Bożego okazanego ludziom ${ }^{94}$. Widząca w miłości i miłosierdziu największe przymioty Boga, pisała Kowalska: „Największą miłość i przepaść miłosierdzia poznaję we Wcieleniu Słowa, w Jego odkupieniu..."95. Wydaje się, że na Zachodzie nieproporcjonalnie mało uwagi - co staje się wyraźne, gdy sięga się do poglądów Ojców Kościoła ${ }^{96}$ - poświęca się wydarzeniu Wcielenia widzianemu właśnie w kategoriach miłosiernej miłości zbawiającej człowieka ${ }^{97}$. Z kolei związek Wcielenie-Męka zdecydowanie domaga się poważniejszej refleksji i uwzględnienia w głoszeniu Ewangelii (za dużo w przepowiadaniu „rozdzielenia” tajemnic wiary, zamiast ich jednoczenia z „rozróżnieniem” ${ }^{98}$.

\section{Theosis z punktu widzenia tajemnicy Wcielenia (św. Maksym)}

\section{Bóg i człowiek „bez zmieszania i bez rozdzielania”}

Katechizm Kościoła Katolickiego odwołuje się do sentencji św. Atanazego: „Istotnie, Syn Boży stał się człowiekiem, aby uczynić nas Bogiem", i podtrzymuje tak mocno akcentowany przez Ojców Kościoła

93 Por. Benedykt XVI, Adhortacja apostolska O Eucharystii, źródle i szczycie życia i misji Kościoła „Sacramentum caritatis”, nr 11.

94 Por. SF, s. 160.

$95 \quad \mathrm{Dz} 180$.

96 Prawosławny teolog John Meyendorff uważa, że na całą historię dogmatu chrystologicznego należałoby patrzeć z perspektywy Odkupienia, bowiem jest ona uwarunkowana ideą Wcielenia Słowa jako zbawienia człowieka - por. J. Meyendorff, Teologia bizantyjska..., dz. cyt., s. 150.

97 Leon Wielki np. widzi we Wcieleniu schylenie się (zstąpienie) miłosierdzia, mówi też o wielkiej tajemnicy miłosierdzia oraz o zrządzeniu miłosierdzia (por.: LWM, $23,2 ; 28,1 ; 29,1 ; 30,5)$.

98 W tym podpunkcie artykułu korzystałem również ze swojego wcześniejszego tekstu: S. Zatwardnicki, Być jak Bóg, stać się Bogiem, „Biblioteka Kaznodziejska" (2012) nr 6, s. 20-27. 
związek pomiędzy Wcieleniem a przebóstwieniem: „Słowo stało się ciałem, by uczynić nas «uczestnikami Boskiej natury» (2 P 1, 4)"99. Bóg, który stał się człowiekiem, umożliwił swoją łaską człowiekowi, by ten stał się tym, kim Bóg jest w swojej naturze ${ }^{100}$. Ta „współzależność pomiędzy humanizacją Boga a przebóstwieniem człowieka"101 znajduje swoją podstawę w tajemnicy Narodzenia Pańskiego, kiedy to dokonuje się admirabile commercium (Ratzinger powie: „alchemia bytu"102): Słowo przyjmuje nasze człowieczeństwo, przez co natura ludzka zostaje wyniesiona do godności Bożej, a człowiek uzyskuje możliwość uczestniczenia w Bożej naturze Słowa ${ }^{103}$.

Syn Boży nie porzuca człowieczeństwa, owszem przez powstanie z martwych i wstąpienie do nieba człowieczeństwo zostaje uwielbione, a choć w uwielbionym Chrystusie należy rozróżniać człowieczeństwo i Bóstwo, to nie wolno ich rozdzielać (Chalcedon!), a w takim razie można człowieczeństwu przypisywać to, co z natury należało do Bóstwa Słowa ${ }^{104}$. W ten sposób „pierworodny między wielu braćmi” $(\mathrm{Rz} 8,29)$ staje się bramą do przebóstwienia swoich braci, a samo przebóstwienie należy rozumieć maksymalnie, bo skoro uwielbione człowieczeństwo Chrystusa znajduje swoje „miejsce” w Bogu, a Chrystus nie przestaje być współistotny nie tylko Ojcu, ale i ludziom, to znaczy, że nasza przyszłość w Bogu nie może być różna/mniejsza od Jego „teraźniejszości”. A zatem można mówić o symetryczności pomiędzy „uczłowieczeniem” Boga (staje się współistotny ludziom) a „przebóstwieniem” człowieka (stajemy się - jak to możliwe? - „współistotni” Bogu).

Oczywiście na przebóstwienie człowieka należy spojrzeć z perspektywy chrystologicznej, co dobrze uchwycił św. Maksym Wyznawca, według którego „synteza Chrystusa” staje się swoistą „formułą światową" opisującą łączenie się struktur całej rzeczywistości nie przez „mieszanie”, ale właśnie na drodze „syntezy” dokonującej się, mówiąc

99

Katechizm Kościoła Katolickiego, dz. cyt., nr 460.

Por. H. Paprocki, Przebóstwienie, [w:] Encyklopedia Katolicka, t. XVI, red. E. Gigilewicz, Lublin 2012, s. 608.

B. Sesboüe, J. Wolinski, Bóg zbawienia. Tradycja, reguła i symbole wiary. Ekonomia zbawienia. Rozwój dogmatów trynitarnych i chrystologicznych (Historia dogmatów, t. I, B. Sesboüe (red.), tłum. P. Rak, red. nauk. wyd. pol. T. Dzidek, Kraków 1999, s. 303.

Por. J. Ratzinger, Kościót. Pielgrzymująca wspólnota wiary..., dz. cyt., s. 73.

Por. Benedykt XVI, Audiencja generalna: „Przedziwna wymiana” (04.01.2012), „L'OssRom” (PL) (2012) nr 3, s. 28.

Por. Międzynarodowa Komisja Teologiczna, Wybrane zagadnienia chrystologii..., dz. cyt., V, B. 
językiem Chalcedonu, „bez zmieszania i bez rozdzielania”. Jest możliwe, by to, co stworzone, przez otrzymanie łaski mogło zjednoczyć się z tym, co niestworzone, tak że człowiek stanie się wszystkim (otrzyma wszystko), czym jest Bóg, z wyjątkiem tożsamości natury ${ }^{105}$, ale nie przestanie być sobą ${ }^{106}$. Właśnie $z$ tej perspektywy Maksymowo-chalcedońskiej trzeba by patrzeć na tajemnicę przebóstwienia człowieka: „w chrześcijaństwie ponad wszelką miarę - zauważa Kongregacja Nauki Wiary - bez unicestwiania w morzu Absolutu osobowego »ja «, z zachowaniem statusu stworzenia, spełniają się wszystkie pragnienia zawarte w modlitwie innych religii”, bo przebóstwiony człowiek „wcielony w Chrystusa Syna Bożego przez naturę, przez Jego łaskę staje się uczestnikiem natury Boskiej, «synem w Synu»"107.

\section{Theosis dzięki zjednoczeniu woli człowieka z wolą Boga}

Przebóstwienie znajdujące swoją podstawę we Wcieleniu nie dokonuje się jednak automatycznie, jak to niektórzy próbowali zarzucać Ojcom Kościoła, lecz zakłada współpracę człowieka z Bogiem; ten Bogoczłowieczy proces polegać będzie na zjednoczeniu woli ludzkiej i Boskiej, czego modelem i fundamentem jest oczywiście znów Chrystusowy sposób dokonywania się rzeczywistej jedności woli (bo przecież nie jakiegoś ich współistnienia „obok” siebie, bez zjednoczenia) przez poddanie się woli ludzkiej Bogu. Ortodoksyjnie chrystologiczny Maksym Wyznawca zwracał uwagę właśnie na wolę Chrystusa związaną z jego rzeczywistym człowieczeństwem, z kolei człowiek „uczy” się od Chrystusa siebie samego, w tym tego, że jedynie wychodząc z siebie,

105 Por.: H. U. von Balthasar (wybór tekstów: W. Löser), W petni wiary, tłum. J. Fenrychowa, Kraków 1991, s. 545 i 547; A. Warkotsch, Wprowadzenie, [w:] Maksym Wyznawca, Antologia życia wewnętrznego. Dialog o życiu wewnętrznym. Księga Miłości. Księga Oświeconych. Wykład Modlitwy Pańskiej. List o miłości, tłum. A. Warkotsch, Poznań b.r.w., s. 67.

106 Grzegorz Palamas, by poradzić sobie z tym paradoksem (być jak Bóg, nie będąc Bogiem) wprowadzał rozróżnienie na istotę Boga oraz przebóstwiające niestworzone energie, co przyjęła za nim teologia prawosławna. To „rozróżnienie pomiędzy Bogiem niedostępnym a Jego partycypacjami (czy władzami) pozwala chrześcijanom wschodnim - przy pełnym zachowaniu różnorodności natur-mówić o «konsubstancjalności» $\mathrm{z}$ Bogiem oraz rozumieć przebóstwienie w sensie absolutnym" (Y. M.-J. Congar, Człowiek i przebóstwienie w teologii prawosławnej, tłum. L. B. i St. G., „Znak” (1968) nr 7-8, s. 855). Wydaje mi się jednak, że w ten sposób pojęte przebóstwienie jest swego rodzaju „ucieczką do przodu” przed radykalizmem Boga, która w pewnym sensie „gasi Ducha”; na tym tle Tomaszowe widzenie istoty Boga jawi się jednak bardziej jako Dobra Nowina. 
może odnaleźć siebie w Bogu ${ }^{108}$, co z kolei jest możliwe tylko dlatego, że Pierworodny stał się nie tylko naszym bratem, ale też poniekąd Ojcem w tym sensie, że „zrodził” swoich braci, bo przez przyjęcie ludzkiej woli zbawił ją, by mogła odtąd wypowiadać swoje fiat Bogu. Ontologiczną jedność (unię hipostatyczną) należy według Ojców Konstantynopola III widzieć w konkretnej egzystencji Chrystusa jako komunię dwóch woli, które mimo iż pozostają oddzielne (Boska wola nie wchłania ludzkiej!), to tworzą rzeczywistą jednośćc ${ }^{109}$. Chalcedońskie „bez zmieszania i bez rozdzielania” zostaje przypisane również zjednoczeniu woli ludzkiej i Boskiej Chrystusa ${ }^{110}$. W ten sposób w miłości dokonująca się jedność nie jest mniej doskonała niż naturalna, owszem według Ratzingera odpowiada ona najwyższej jedności trynitarnej ${ }^{111}$. W chrystologii Soboru 680-681 kryje się oczywiście antropologia; jeśli - co odsłania się przed nami w życiu Chrystusa - „osoba Syna Przedwiecznego może aż do samych korzeni przenikać ludzką rzeczywistość Chrystusa, nie niszcząc jej ani w niczym nie zmieniając"112, to znaczy, że ludzka wola musiała zostać stworzona „od początku” jako „nastawiona” na Boga i znajdująca swoje urzeczywistnienie dopiero w Nim. Również wolność człowieka - paradoksalnie! - znajduje swoją realizację dopiero w „tak” powiedzianym Bogu, wola ludzka „przez przylgnięcie do woli Bożej nie ulega zniszczeniu, lecz osiąga własną doskonałość"113, dopiero wtedy staje się bowiem „boska"114. Za świętym teologiem prawosławnym Mikołajem Kabasilasem (ur. między 1319 a 1323 r., zm. prawd. po 1397/1398 r.) można powiedzieć, że ,jesteśmy zjednoczeni z Chrystusem nieskończenie bardziej niż sami z sobą”, i właśnie „to zjednoczenie z Chrystusem czyni nas przez łaskę uczestnikami tego wszystkiego, czym jest Chrystus"115.

108 Por.BenedyktXVI,Audiencjageneralna:,Św.Maksym Wyznawca”(25.06.2008), „L'OssRom” (PL) (2008) nr 9, s. 51 [dalej cyt. SMW].

Por. J. Ratzinger, Chrystus i Jego Kościót, tłum. W. Szymona, Kraków 2005, s. 117.

Por. Sobór Konstantynopolitański (680-681). Wyktadwiary, nr 14.16 i 19, [w:] DSP.

Por. J. Ratzinger, Patrzeć na przebitego. Szkice o chrystologii duchowej, tłum. J. Merecki, Kraków 2008, s. 35. do Zmartwychwstania, tłum. W. Szymona, Kielce 2011, s. 174. wolności” (01.02.2012), „L'OssRom” (PL) (2012) nr 4, s. 45.

115 Cytuję za: Y. Spiteris, Ostatni Ojcowie Kościoła. Kabasilas, Palamas (Bogosłowije, 5), tłum. B. Widła, Warszawa 2006, s. 81. 
Chrystus, „,chociaż był Synem, nauczył się posłuszeństwa przez to, co wycierpiał. A gdy wszystko wykonał, stał się sprawcą zbawienia wiecznego dla wszystkich, którzy Go słuchają" (Hbr 5, 8-9). Z kolei uczniom dane było zobaczyć tę odkupiającą nas wszystkich lekcję „uczenia się posłuszeństwa” dzięki temu, że sam Mistrz uchylił rąbka tajemnicy (swojej, naszej oraz naszego odkupienia) w Getsemani (por. $\mathrm{Mk}$ 14, 32-41).

Dramat naszego odkupienia polega na tym - tłumaczył papież-senior że Jezus ciągnie ku górze naszą wolę, nasz sprzeciw wobec woli Bożej, a także nasz sprzeciw wobec śmierci oraz grzechu, i łączy go z wolą Ojca: «nie moja wola, lecz Twoja”. W tej przemianie „nie” w „tak”, w tym włączeniu woli stworzenia w wolę Ojca przemienia On ludzkość i nas zbawia ${ }^{116}$.

Dramatyczne zmaganie, jakie w tamtej chwili staje się udziałem Chrystusa, ujawnia konflikt istniejący między wolą ludzką a Boską, odzwierciedla właściwą naturze ludzkiej skłonność do tego, by wolności upatrywać w powiedzeniu Bogu „nie”, i w końcu ukazuje również zwycięstwo możliwe dzięki temu, że w Chrystusie naturalna ludzka wola zostaje włączona w to nastawianie, które otrzymuje od Boskiej Osoby Syna powierzającej się Ojcu ${ }^{117}$. Uniżający się Logos przyjmuje wolą ludzką i mówi do Boga wraz z ,ja” człowieka, a przekazując mu swoje „Ja”, zbawia go i czyni Bogiem ${ }^{118}$.

Jeśli tak się sprawy mają z zielonym drzewem Syna, cóż innego miałoby się stać z suchym drzewem chrześcijan (por. Łk 23 ,31)? Na wzór Chrystusa, dzięki Wcieleniu oraz Odkupieniu, egzystencja wierzących zostanie również naznaczona wymiarem kenotycznym - będzie to wychodzenie z siebie z miłości do Boga, a wyrazem tego będzie poddanie swojej woli Bogu - posłuszeństwo Krzyża ${ }^{119}$ czy może Krzyż posłuszeństwa, przy czym - podkreślmy - możliwy do udźwignięcia jedynie dzięki zjednoczeniu z pierworodnym Ukrzyżowanym. Ten Exodus - wychodzenie z samego siebie przez krzyżową bramę - dokonał się już w życiu Matki Chrystusa ${ }^{120}$. Droga ku przebóstwieniu idzie w odwrotnym kierunku niż ten, którym podążyli Adam i Ewa: chodzi

116 Benedykt XVI, Audiencja generalna w Wielka Środę: „Tajemnica Wielkiego Tygodnia umacnia wiare” (20.04.2011), „LOssRom” (PL) (2011) nr 6, s. 31.

Por. Benedykt XVI, , «Tak» powiedziane Bogu szczytem wolności”, dz. cyt., s. 45.

Por. J. Ratzinger, Patrzeć na przebitego..., dz. cyt., s. 37.

Por. Ch. Schönborn, Ikona Chrystusa, dz. cyt., s. 141.

Zwracał na to uwagę kardynał Ratzinger - por. J. Ratzinger - Benedykt XVI, H. U. von Balthasar, Maryja $w$ tajemnicy Kościoła, tłum. W. Szymona, Kraków 2007, s. 65 . 
o pokorę na wzór Drugiej Ewy oraz Drugiego Adama, który wybawił nas od grzechu pychy.

„Adam, powolny diabłu aż do złamania wierności Bogu, w swojej osobie wszystkim wysłużył śmierć; Jezus posłuszny Ojcu aż do śmierci krzyżowej - kazał Leon Wielki - w swojej osobie wszystkim przyniósł życie" ${ }^{121}$, dlatego - napominał papież - „nie odbiegajmy w pokorze od Niego, jeśli w chwale Mu chcemy być podobni” ${ }^{122}$.

\section{Zakończenie. Głębia przyzywa głębię (Psalmista)}

Wykształcone teologiczne głowy pochylają się z uznaniem nad Dzienniczkiem prostej Faustyny Kowalskiej, z kolei mający odpowiednie przygotowanie św. Jan od Krzyża potrafił sam dokonać przekładu z natury niepojęciowego, wyrażanego językiem symbolicznym i poetyckim doświadczenia, na język filozoficzno-teologiczny. Zaś w osobie Maksymiliana Marii Kolbego złączyło się nie tylko wykształcenie teologiczno-filozoficzne oraz doświadczenie mistyczne Świętego, w genialnych logiczno-teologicznych intuicjach franciszkanina dają o sobie znać również jego wyjątkowe zdolności matematyczno-przyrodnicze ${ }^{123}$. Przekonania świętych czy doświadczenia mistyków, nie tylko tych przed chwilą wspomnianych, których wypowiedzi przywołano w niniejszym tekście, potwierdzają możliwość przebóstwienia człowieka, jak również teandryczny charakter zarówno finalnego efektu (jedność człowieka i Boga „bez zmieszania i bez rozdzielania”), jak i drogi do niego prowadzącej (Bosko-ludzka współpraca, zjednoczenie woli człowieka z Bogiem dokonujące się również według chalcedońskiego paradygmatu, obowiązującego także w wieczności). Przy czym droga ta wiedzie ścieżką wąską i stromą, na szczycie której widnieje Krzyż, do którego to wniosku prowadzą rozważania chrystologiczne i mistyczne. Na przykład Doktor Karmelu właśnie w śmierci krzyżowej zmysłów i ducha - pisał o tym w Drodze na Górę Karmel ${ }^{124}$ - upatrywał drogi do

$\overline{121}$ LWM, 25, 4.

122 Tamże, 23, 5.

123 Maksymilian w czasie rzymskich studiów uczęszczał dodatkowo na wykłady z nauk ścisłych, czego jednym z efektów były „opisy, wykresy i obliczenia dotyczące budowy pojazdu międzyplanetarnego"(L. B. Dyczewski, Św. Maksymilian Maria Kolbe, [w:] M. M. Kolbe, Pisma. Cz. I, przygot. do druku P. Sotowski, Niepokalanów 2007, s. 15).

124 Korzystam z wydania: Św. Jan od Krzyża, Droga na Górę Karmel, [w:] JKD, s. $139-401$. 
zjednoczenia z Bogiem ${ }^{125}$, a w pełni mistycznego zjednoczenia trzeba by - uważa ks. Chmielewski - widzieć prawdziwą chrystomorfozę ${ }^{126}$.

Wolno w tej zgodności wniosków płynących z teologii i mistyki widzieć kompatybilność Objawienia i teologii dogmatycznej z jednej strony oraz doświadczenia duchowego i teologii mistycznej z drugiej. Należy jednak dostrzec coś więcej: wzajemne naświetlanie się, dzięki któremu oba typy mądrości zyskują głębsze zrozumienie jeśli nie samej tajemnicy Bosko-ludzkiego zjednoczenia, to przynajmniej jego „intensywności” (ścisłości, głębokości, intymności, ...). Zgodnie ze słowami psalmisty, głębia przyzywa głębię" (Ps 42,8), co w interesującej nas kwestii prowadzi do uznania - choć nie wyjaśnienia - tajemnicy przebóstwienia człowieka ,symetrycznej” względem „uczłowieczenia” Boga: jedna mądrość przyzywa drugą mądrość i daje pełniejsze pojęcie theosis, które polega z kolei na tym, że miłość przyzywa miłość: „poprzez zstępującą ekstazę Boga oraz wstępującą ekstazę człowieka następuje ich mistyczne spotkanie i zjednoczenie" ${ }^{127}$ (Palamas), jak „Wcielenie Boga dokonuje się przez umiłowanie człowieka”, tak „przebóstwienie człowieka dokonuje się przez umiłowanie Boga” (św. Maksym) ${ }^{128}$, przy czym ludzka miłość zostaje wyniesiona na poziom miłości Bożej, by kochać odpowiednio. Nawiązując raz jeszcze do Doktora Mistycznego odwołującego się do słów Psalmisty (tyle że tłumaczonych: „przepaść przepaści przyzywa”), można powiedzieć, że łaska udzielona wierzącym przez Boga przyzywa łaski przebóstwienia: „,́́wiatło łaski, które Bóg uprzednio dał duszy i którym wzrok jej przepaści duchowych otworzył na światło Boże, a przez to uczynił ją sobie przyjemną, przyzwało drugą przepaść łaski, którą jest boskie przeobrażenie duszy w Boga" ${ }^{129}$. Współistotności Chrystusa z ludźmi (braćmi) musi odpowiadać nasza współistotność z Bogiem (Ojcem), a choć substancjalnej tożsamości między Bóstwem a człowieczeństwem być nie może, nie musi to oznaczać, że zjednoczenie człowieka z Bogiem jest czymś mniejszym. Warto, wydaje mi się, w dalszych badaniach teologicznych zwracać uwagę na Tego, który po swoim Zmartwychwstaniu w ciele „wrócił” do Ojca: czy uwielbione człowieczeństwo Syna

125 Por. JKD, s. 207.

126 Por. PCJK, s. 66. Doktor Karmelu widzi nawet w kontemplacji wiecznych, jak pisze, tajemnic Wcielenia „cząstkę szczęśliwości” duszy w wieczności. Według mistyka tajemnice Boga-Człowieka należą do najwznioślejszych tajemnic kryjących się w Bogu - por. JKD, s. 695-696.

127 PCGP, s. 108.

128 Cyt. za: H. U. von Balthasar, W petni wiary, dz. cyt., s. 548.

JKD, s. 789. 
Bożego rzeczywiście „znajduje się” w Trójcy czy nie? Oto pytanie, które wskazuje na przyszłość każdego wierzącego.

Nie należy się bać Pasterza, który według słów kard. Ratzingera „szuka nas tam, gdzie jesteśmy, lecz nie po to, abyśmy tam pozostali, lecz po to, abyśmy poszli tam, gdzie On jest, abyśmy wznieśli się ponad nas samych"130. Na przebóstwienie trzeba bowiem spoglądać $\mathrm{z}$,wnętrza" tajemnicy Chrystusa: theosis nie zaciera różnicy między Stwórcą a stworzeniem (byłby to „monofizytyzm”, po prostu panteizm), których należy rozróżniać, ale których nie wolno już odtąd widzieć rozdzielonych („nestorianizm”). Wola ludzka - twierdzi autor Trzech okresów życia wewnętrznego, który teologię życia duchowego widzi jako zastosowanie dogmatów w życiu chrześcijańskim - „będzie istniała nawet w miłości uszczęśliwiającej; nie jest ona fizycznie wchłonięta przez Boga, jakby powiedzieli panteiści”"131, właśnie ta „inność” Stwórcy i stworzenia, jak utrzymuje Kongregacja Nauki Wiary, jest dobra i umożliwia zjednoczenie w miłości, na wzór misterium trynitarnego, w którym Syn jest wiecznie „,innym” od Ojca, a jednak w Duchu Świętym jest Ojcu współistotny ${ }^{132}$. Miłość rzeczywiście okazuje się największa, sprawia ona nie tylko częściowe i niejasne (,jakby w zwierciadle”), ale doskonałe („twarzą w twarz”) widzenie Boga oraz prowadzi do poznania Go tak, jak sami zostaliśmy poznani (por. 1 Kor 13, 10-13). A zostaliśmy poznani doskonale przez Boga miłującego tak doskonale - dzięki unii hipostatycznej, bez której z kolei nie byłoby możliwe nasze doskonałe zjednoczenie $\mathrm{z}$ Bogiem $\mathrm{z}$ miłości do Niego ${ }^{133}$ - miłości ludzkiej i Boskiej zarazem, skoro, jak twierdzą mistycy, Bóg podnosi człowieka do miłowania Go Jego własną miłością. I tę Bosko-ludzką miłość człowieka do Boga trzeba chyba widzieć jako dokonującą się „bez zmieszania i bez rozdzielania”.

Słowa kluczowe: Benedykt XVI, Chrystus, Bóg, człowiek, Maryja, przebóstwienie, Sobór w Chalcedonie, III Sobór w Konstantynopolu, zjednoczenie, mistyka, teologia, chrystologia, antropologia, natura, wola, Jan od Krzyża, Faustyna Kowalska, Maksymilian Kolbe.

$130 \quad$ Por.: J. Ratzinger, Duch liturgii, tłum. E. Pieciul, Poznań 2002, s. 111-112.

131 R. Garrigou-Lagrange, Trzy okresy życia wewnętrznego, dz. cyt., s. 852. Por. OF 14. 